\title{
Maloqueiros e seus palácios de barro: o cotidiano doméstico na Casa Bandeirista
}

\section{Paulo Eduardo Zanettini}


São Paulo

Dezembro de 2005 